\title{
A RUPTURA DO PACTO SOCIAL NO PENSAMENTO DE SADE ${ }^{1}$
}

\author{
Mônica Guimarães Teixeira do AMARAL ${ }^{2}$
}

- RESUMO: As obras de Sade procuram retratar as práticas corruptas e libertinas presentes no regime despótico de Luís XV, apontando invariavelmente a "alcova" como lugar privilegiado de transformação do corpo e da mente e, ao mesmo tempo, de produção filosófica. A atualidade do pensamento de Sade revela-se no fato de colocar como tendência da modernidade, a constituição narcísica da subjetividade que, em sua variante político-social, aparece sob a forma do conformismo político. Este artigo pretende apresentar o pensamento de Sade como uma crítica aos liames sociais, o que conduz à ruptura da idéia de pacto social formulada por Rousseau. A doutrina sem compaixão de Sade torna-se filosofia negativa na medida em que fornece os fundamentos da crítica à razão instrumental. Sendo pessimista quanto aos rumos do existente, a teoria sadiana aponta a "animalidade" humana como possibilidade de transcendência da artificialidade dos laços sociais.

- UNITERMOS: Filosofia anti-humanista; verdade; sexualidade; transcendência.

“Com que direito aquele que a mentira adstringe
Pretende submeter-se ao erro que o atinge?
Careço eu do Deus que a sábia mente abjura
Pra a mim mesmo explicar as leis da mãe natura?
Nela tudo se move, e o seu seio criador
Age sem precisar da ajuda dum motor"...
"Por mais que à agitação seu órgão nos arraste
Há que ceder-lhes sem remorso e sem desgaste,
E, não escrutando leis nem costumes lembrando,
Ardentemente ao erro irmo-nos entregando,
Que sempre por suas mãos no-lo ditou natura.
Respeitemos tão-só o que ela nos murmura"...
"Vejamos como o raio em suas mãos fatais
Fulmina ao acaso e como os filhos e os pais,
Os templos, os bordéis, os crentes, os bandidos,
Tudo à natura apraz, carente de delitos.
Servimo-la nós também ao cometer o crime:
Mais nossa mão o espalha e mais aquela o estima"..

Donatien Alphonse François de Sade A verdade...(1989).

1. Este texto foi elaborado por ocasiao da realização do curso de Fundamentos Filosóficos da Psicologia e da Psicanálise, oferecido pelo Centro de Lógica, Epistemologia e História da Ciência da UNICAMP durante o ano de 1989.

2. Departamento de Psicologia da Educação - Faculdade de Ciências e Letras - UNESP - 14800 - Araraquara - SP. 


\section{Introdução}

Pretende-se, no presente ensaio, examinar as idéias do Marquês de Sade, particularmente as que o autor expõe em $A$ filosofia na alcova (1968), contrapondo-as às teses de Jean-Jacques Rousseau sobre o pacto social, presentes em sua obra $O$ contrato social, particularmente no Livro I, Cap. VI. (Do pacto social), (s.d.).

Algumas das reflexões aqui apresentadas acerca do pensamento filosófico de Sade apóiam-se nas referências de Roland Barthes (1979), encontradas no ensaio "Sade, Fourier, Loiola".

Neste trabalho restringimo-nos, porém, às reflexões que Barthes desenvolve sobre Sade. No prefácio desta obra já se tem uma idéia das intenções do autor em resumir pensadores tão diversos: " De Sade a Fourier, o que se desvanece é o sadismo; de Loiola a Sade, é a interlocução divina. Quanto ao resto, a mesma escrita, a mesma volúpia de classificar, a mesma paixão cortante (de cortar o corpo crístico, o corpo imolado, a alma humana), a mesma obsessão enumerativa (contar os pecados, os suplícios, as paixões e os próprios erros de cálculo), a mesma prática da imagem (da imitação, do quadro, da sessão), a mesma função do sistema social, erótico, fantasmático"'(1979, p. 9).

Procuramos também fundamentar nossa exposição nas críticas levantadas por Adorno e Horkheimer, em Dialética do esclarecimento (1985) em relação ao pensamento de Sade que, segundo eles, proclama como natural a dominação dos mais fracos pelos mais fortes. Saliente-se ainda que alguns de nossos comentários sobre a estrutura da obra Dialética do esclarecimento inspiram-se nas reflexões de Martin Jay, apresentadas no artigo "Positive and Negative Totalities..." (1986).

A obra Dialética do esclarecimento apresenta-se como um discurso fragmentário, que praticamente substitui o sistema hegeliano-marxista. Adorno, em particular, considera que seja possível obter noções esclarecedoras de uma "totalidade fraturada" a partir do estudo de elementos particulares do real. O particular é concebido como "revelação repentina" de um real "não totalizado". O I Excurso da obra em questão trata da dialética do mito e do esclarecimento na Odisséia, de Homero, considerada como um dos testemunhos mais precoces da civilização burguesa ocidental. O II Excurso trata de autores como Sade, Kant e Nietzsche, os quais Horkheimer e Adorno concebem como os "implacáveis realizadores do esclarecimento". Na tentativa, no entanto, de elaborar uma série de ensaios, sem a pretensão de apanhar a totalidade do conceito, os autores recorrem a estes pensadores como forma de elucidar a dialética do particular. Somente Filosofias Negativas, como as formuladas por Kant, Nietzsche e Sade é que, contraditoriamente, poderiam fornecer subsídios à razão emancipatória em uma sociedade dominada pela Indústria Cultural, como a do século XX.

O artigo de Michel Lebrun "Les perils de la nature" (1967) foi fundamental para o propósito de contextualizar os pensamentos de Sade e de Rousseau em meio à produção filosófica do século XVIII. Recorremos a este artigo por ser bastante esclarecedor quanto aos temas tratados no presente ensaio, ou seja, as idéias de Sade 
e Rousseau sobre o pacto social e, particularmente, pelo fato de demonstrar como o pensamento libertino veio romper com o "otimismo" reinante no pensamento filosófico do século XVIII. Ao mesmo tempo, o artigo de Lebrun elucida, mesmo que a partir de um outro enfoque, as idéias de Adorno e Horkheimer a respeito das Filosofias Negativas.

\section{Sobre Sade}

R. Barthes salienta a importância de Sade, antes de tudo, por ter "inventado um discurso imenso, baseado nas suas próprias repetições (e não nas dos outros), trocado em pormenores, surpresas, viagens, ementas, quadros, configurações, nomes próprios etc.; em resumo, a contracensura consiste em criar o romanesco a partir do interdito" (1979, p. 126).

As aventuras sadianas retratam, segundo o autor, a sociedade de Luís XV, contemporânea à juventude de Sade. A sociedade de libertinos corresponde à realidade da própria aristocracia da época, ou mais especificamente, da "classe dos financeiros, tratantes e prevaricadores, numa palavra: exploradores, tendo a maior parte deles enriquecido nas guerras de Luís XV e com as práticas corruptas do despotismo" (Barthes, p. 129-30). Os súditos retratados nas obras de Sade pertencem ao subproletariado industrial e urbano, ou aos servos do feudalismo, que ainda subsistiam em algumas regiões da Europa.

As relações de classe, segundo Barthes, aparecem retratadas em Sade como se fossem um modelo a reproduzir na pequena sociedade de libertinos. Trata-se de uma "re-produção", não de um quadro histórico, mas sim de uma prática social em que exploradores e explorados opõem-se radicalmente. Isto fica evidenciado nas relações que os libertinos mantêm com Augustin, um jovem jardineiro, em A filosofia na alcova, associando-o, "como manequim às suas lições, e como súdito aos seus prazeres" (Barthes, p. 155). Nota-se também que Augustin é excluído da cena, quando Dolmancé se põe a ler o panfleto "Franceses, só mais um esforço se quereis ser republicanos". O súdito é excluído da linguagem séria dos libertinos; ao mesmo tempo, segundo Barthes, "o discurso que inaugura a moral republicana é, paradoxalmente, um pacto de secessão lingüística..." (Horkheimer, 1985, p. 155). A cena erótica que une os corpos opõe, ao mesmo tempo, a linguagem da aristocracia à dos súditos.

É importante acrescentar, a título de apresentação das idéias sadianas e de sua linguagem específica, que os romances de um autor tão controvertido como este, considerado por alguns como um autor pornográfico, ou como alguém que melhor descreveu as patologias sexuais, ou ainda enquanto crítico literário, talvez deva ser estudado como um pensador que entrelaça textos compactos, em que expõe grandes dissertações filosóficas, e páginas repletas de diálogos e trechos entrecortados onde apresenta "a orgia, a cena libidinosa ou criminal" (Barthes, p. 143). O estilo da narração 
sadiana rompe com qualquer leitura estruturalista, sem apresentar um sentido definido, ou mesmo uma progressão de sentidos, e muito menos algo por concluir.

Segundo Barthes, “a rapsódia sadiana é dirigida sem ordem: viagens, roubos, assassínios, dissertações filosóficas, cenas libidinosas, fugas, narrações segundas, programas de orgia, descrições de máquinas etc..." (p. 138).

O grupo sadiano se constitui para o leitor como "quadros vivos" , e torna-se cena para os participantes. Entrelaçam-se algo de estático, pictórico e o trabalho de encenação próprio ao que Barthes denomina "quadros vivos". O leitor é tratado como se fosse um espectador de uma peça de teatro, como se fosse convidado a encenar, a acrescentar, a transformar o quadro.

O desejo e a imaginação assumem uma importância vital no projeto sadiano de libertação do corpo de toda e qualquer moralidade. "O que constitui o valor do sexo é o espírito. O espírito é simultaneamente uma efervescência da cabeça ('Vi a esporra exalar-se dos seus olhos') e uma garantia de rentabilidade, pois o espírito prescreve, inventa, aperfeiçoa..." (Barthes, p. 165).

É preciso salientar que Sade foi um dos autores que acabou instaurando o pensamento anti-humanista na modernidade e o único a questionar a idéia de vínculo social. Nem por isso pensa o homem isolado, sem ligações, referindo-se, muitas vezes, a relações mais diretas, não mediadas pelo aparato moral e político do Estado.

A relação sadiana, no interior do grupo libertino, é sempre, como afirma Barthes (recorrendo a Lacan), de "desforra", combinando-se as figuras ora de vítima, ora de perseguidor. Todas as relações tendem a formar uma cadeia erótica que vem substituir o par monogâmico.

Sade, em A filosofia na alcova, elabora uma crítica radical a todos os liames que unem os homens, ou seja, às relações de parentesco, de amor, de amizade etc., assimcomo apresenta uma crítica radical às idéias religiosas. As relações humanas encontram-se permeadas pela imoralidade, conduzindo à ruptura de todo pacto social.

\section{Confrontando Sade e Rousseau}

Rousseau, particularmente no capítulo em que trata do pacto social, em O contrato social, entende que os homens são conduzidos a estabelecer uma espécie de contrato social, cuja cláusula essencial refere-se à necessária “'alienação total de cada associado, com todos os seus direitos, em favor de toda a comunidade; porque, primeiramente, cada qual se entregando por completo e sendo a condição igual para todos, a ninguém interessa torná-la onerosa para os outros'” (p. 30).

O contrato social, segundo Rousseau, viria solucionar o problema fundamental colocado pelo interesse comum de autoconservação diante da necessidade de preservar a liberdade de cada homem. O autor enuncia essa questão do seguinte modo: "Encontrar uma forma de associação que defenda e proteja de toda a força 
comum a pessoa e os bens de cada associado, e pela qual, cada um, unindo-se a todos, não obedeça senão a si mesmo, e permaneça tão livre como anteriormente" (p. 31).

As bases desse contrato assentam-se sobre o pacto social, cujas cláusulas são tacitamente admitidas e reconhecidas até que se imponha a necessidade de violá-lo, momento em que é restituída ao homem a liberdade natural em detrimento da liberdade convencional.

A pessoa pública assume a forma de "República" ou "corpo político", cujos interesses devem saber expressar a vontade geral e se sobrepor aos interesses da "pessoa particular de cada contratante" (p. 31). Supõe que esse ato de associação deve produzir "um corpo moral e político", cujo comando supremo seria representado pela pessoa pública, denominada de "Estado, quando é passivo; soberano, quando é ativo; autoridade, quando comparados a seus semelhantes" (p. 31, grifos no original). Esse "corpo moral e coletivo" deveria ser capaz de expressar os interesses de cada um de seus membros. Embora defenda essa idéia de unidade, faz o autor uma distinção entre os associados, denominados genericamente de 'povo', no que se refere ao poder de legislar: cidadãos, os "participantes na autoridade soberana", e vassalos, aqueles "sujeitos às leis do Estado" (p. 31, grifos no original).

Sade é contrário à idéia de pacto social, pois considera que o aparato moral e político do Estado foi montado para bloquear a imaginação, ao mesmo tempo em que mascara a desigualdade, já que apenas metamorfoseia a dominação e não a modifica em sua essência. Em $A$ filosofia na alcova, Sade expõe suas idéias acerca da religião, dos costumes, da política e, no afã de produzir transformações na pequena Eugénie, que, por sua vez, demonstra-se dócil à "educação", propõe que o espaço privado seja o lugar privilegiado de transformação do corpo e da mente. Pretende, desse modo, promover o total desbloqueio da imaginação e, assim, restituir ao sujeito o poder sobre seu corpo. A idéia é fazer com que o sujeito utilize seu corpo com a finalidade de obter prazer, com plena consciência de si e de seu corpo, e não encobrindo-o pelos ditames morais da família, da religião, do Estado etc.

O engodo do pacto, segundo o Marquês de Sade, consiste em pregar uma igualdade aparente e com isso reprimir a possibilidade de o mais fraco rebelar-se. É certo que Rousseau não reconhece nenhuma autoridade natural do mais forte sobre o mais fraco, nem admite que a força faça o direito, no entanto, confere às convenções o espaço de legitimidade da autoridade entre os homens.

O pacto social, segundo Rousseau, "ao invés de destruir a igualdade natural substitui, ao contrário, por uma igualdade moral e legítima a desigualdade física que a natureza pôde pôr entre os homens, fazendo com que estes, conquanto possam ser desiguais em força ou em talento, se tornem iguais por convenção e por direito" (p. 37 , o grifo é nosso). Apesar de salientar a justiça de um pacto que protege os mais fracos dos mais fortes, parte ingenuamente do pressuposto de que o direito à propriedade seja igual para todos. Mesmo considerando que a desigualdade entre os homens se 
origina da desigualdade econômica, propõe que a legitimidade do Estado seja garantida não por condições de ordem econômica e política, mas de ordem psicológica ou moral. Essa questão fica esclarecida quando discursa sobre a igualdade em um sistema baseado em graus distintos de poder e de riquezas: " o que supõe, por parte dos grandes, moderação de bens e de crédito e, do lado dos pequenos, moderação de avareza e ambição"' (p. 60).

Considera-se que o Estado deva ser dirigido pela "vontade geral", "pois, se a oposição dos interesses particulares tornou necessário o estabelecimento das sociedades, foi a conciliação desses mesmos interesses que o tornou possível" (p. 38). Os laços sociais deveriam, pois, basear-se nesse esforço de conciliação que, para Sade, transforma-se no grande engodo do pacto proposto por Rousseau.

Rousseau faz ainda a ressalva de "que não há e nem pode haver nenhuma espécie de lei fundamental obrigatória para o corpo do povo, nem mesmo o contrato social" (p. 32). Abre-se assim a possibilidade de um rearranjo do pacto social, caso não mais corresponda aos interesses da coletividade. Mas, enquanto subsistir o pacto, impõe-se a obrigatoriedade de respeitá-lo.

No entender de Sade, o espaço onde se consolida aquilo que se nega, ou seja, a igualdade, é o da sociedade. É na alcova, no entanto, que aparece a verdade do sujeito, centrada no interesse próprio, no prazer e no egoísmo.

Ao contrário de Rousseau, a única moralidade aceitável por Sade é a do próprio indivíduo. Como conseqüência da união do interesse próprio, do prazer e do egoísmo, tudo se justifica - o roubo, a flagelação, o crime etc. Tornam-se incertos os limites entre o bem e o mal, ficando difícil precisar quais são as ações consideradas criminosas.

No discurso "Franceses, ainda um esforço, se quereis ser republicanos", introduzido em um momento de "síntese" da educação de Eugénie, Sade faz uma espécie de apelo ao antipacto. "Ao se conceder a liberdade de consciência e de imprensa, pensai cidadãos, que com raras exceções, deve-se permitir qualquer ação, salvo aquela que ofende diretamente as bases do Governo, restam-vos muito menos crimes a punir, pois que, com efeito, há muito poucas ações criminosas numa sociedade baseada na liberdade e na igualdade e que, pesando e examinando bem as coisas, nada há de verdadeiramente criminoso, senão aquilo que a lei reprova, pois a natureza nos inspira, ao ditar-nos igualmente vícios e virtudes, tendo em vista a nossa organização, ou, mais filosoficamente ainda, em vista da necessidade que ela tem de um e de outro, o que ela nos sugere é de medida muito incerta, para regular com precisão o que está bem ou o que está mal"' (Sade, 1968, p. 132, o grifo é nosso).

Apesar de salientar o papel das organizações individuais que impelem cada ser humano a esta ou àquela ação, não se pode concordar com R. Barthes, que acredita que os personagens de Sade sejam ineducáveis. Barthes recorre aos personagens Justine e Juliette para demonstrar que o texto sadiano propõe basicamente a "repetição do prazer", tornando-se indecorosa, não porque incita à luxúria e ao crime, mas porque "não revela, não transforma, não amadurece, não educa, não sublima, não completa nem 
recupera nada, a não ser o próprio presente, cortado, sedutor, repetido..." (p. 147). No entanto, se nos remetermos à personagem Eugénie, em $A$ filosofia na alcova, percebe-se nela um verdadeiro processo de transformação pedagógica no sentido, evidentemente, de produzir rupturas com toda e qualquer moralidade que possa bloquear sua imaginação.

No momento em que Sade eleva o prazer como critério máximo em detrimento de todos os outros objetivos, propõe como que uma cisão entre razão e prazer. O esforço pedagógico presente na educação de Eugénie faz-se no sentido de afastá-la das virtudes, abri-la para a imaginação e com isso libertá-la dos grilhões da moralidade e de tudo o que possa sustentar a idéia de pacto social.

Eis o projeto de educação da jovem Eugénie que a Sra. de Saint-Ange pretende levar a cabo com o auxílio de dois outros senhores libertinos: "Trata-se de uma educação: conheci-a no convento, no outono passado, enquanto meu marido estava nas termas. ...O pai é um libertino... que cativei. Enfim, a bela virá...Dolmancé e eu poremos nessa linda cabecinha todos os princípios da mais desenfreada libertinagem, abrasá-la-emos com nossos ardores, alimentá-la-emos com a nossa filosofia, nossos desejos irão inspirá-la, e como quero unir um pouco de prática à teoria, e quero que se demonstre à medida que se disserte, eu te destinei, meu amigo, à colheita dos mitos de Cítera, e Dolmancé à das rosas de Sodoma" (Sade, p. 19, o grifo é nosso).

O prazer encontra-se, pois, nesse projeto, vinculado à voluptosidade, segundo a qual a imaginação exerce um papel fundamental no sentido de reconstruir o universo sensível de acordo com o desejo, e que, ao mesmo tempo, encontra-se mergulhado em "desenfreada" libertinagem. Em seguida a Sra. de Saint-Ange acrescenta: "Experimentarei dois prazeres ao mesmo tempo; o de gozar eu própria essas voluptosidades criminosas, e o de ensiná-las, de inspirar o seu gosto à deliciosa inocente que atraio para nossa rede" (Sade, p. 19). Unir a prática à teoria significa produzir transformações no corpo e na mente. A satisfação obtida nunca se dá de modo solitário para Sade, mas de maneira a constituir uma singularidade conectiva. A pedagogia em Sade envolve a liberação da imaginação, já que pressupõe que o corpo bloqueado seja resultante da ação dos preconceitos e das "virtudes" sobre a imaginação.

A Sra. de Saint-Ange afirma que nada poupará para perverter a jovem Eugénie, "para degradar, aniquilar todos os falsos princípios de moral com que já a possam ter perturbado; com duas lições, quero torná-la tão perversa, tão ímpia, tão devassa, quanto eu própria" (Sade, p. 20, o grifo é nosso). E ainda acrescenta que a função pedagógica da imoralidade dos dois cavalheiros e dela mesma deve ser a de "desarraigar em poucos instantes todas as sementes da virtude que, não fôramos nós, germinariam" (Sade, p. 20).

Prontamente, o "cavalheiro" lhe descreve suas melhores qualidades de mestre libertino: "a irreligião, a impiedade, a desumanidade, a libertinagem..." (Sade, p. 20, o grifo é nosso).

Antes de analisarmos cada uma dessas qualidades, é preciso estudar os princípios que as sustêm. Essas qualidades advêm de um programa que valoriza 
apenas a vida intensamente prazerosa, em que as relações são diretas, espontâneas e procuram romper totalmente com a convenção que embasa o pacto social; Rousseau, ao contrário, considera que "a ordem social é um direito sagrado que serve de alicerce a todos os outros. Esse direito, todavia, não vem da Natureza; está, pois, fundamentado sobre convenções"' (p. 22).

Sade propõe um mundo à imagem da "horda primordial", o grupo espontâneo, que ainda não se metamorfoseou em sociedade política. Rousseau, quando ressalta o papel do pacto social como condição de subsistência do gênero humano, opõe-se a este retorno ao estado primitivo, em que as relações humanas, segundo ele, se conservariam no estado natural.

Sade considera que, em nome da segurança, o Homem se submeteu à lei, domesticou o corpo, aceitou a renúncia, passando assim a admitir as regras de convivência social como sendo razoáveis. Viver tornou-se, segundo o autor, sinônimo de sobreviver.

O contrato social proposto por Rousseau pressupõe, contrariamente ao que pensa Sade, que as forças naturais sejam aniquiladas, o que poderia tornar mais duráveis as aquisições culturais, além de contribuir para o aperfeiçoamento das instituições.

Sade aponta para uma transmutação integral dos valores morais, de acordo com os quais se deve assumir o perigo da vida. Proclama a liberdade e a coragem como os condutores da ação humana.

Já Rousseau salienta o dever e o interesse como sendo as qualidades essenciais para a manutenção da vida em sociedade, pois que "obrigam igualmente as duas partes contratantes a se auxiliarem de forma recíproca, e os próprios homens devem procurar reunir sob essa dupla relação todas as vantagens que disso dependem" (p. 32). Considera que se persistisse o estado natural, as relações entre os homens tornar-se-iam tirânicas, enquanto o pacto social, ao conferir ao "corpo político um poder absoluto sobre todos os seus", e por ser dirigido pela vontade geral, é que seria capaz de restituir aos homens sua soberania.

Analisemos, pois, as qualidades libertinas exaltadas por Marquês de Sade em A filosofia na alcova. Faremos a cada um dos aspectos estudados um contraponto com o pensamento de Rousseau presente em O contrato social.

\section{A irreligião}

Esse é um dos temas mais intensamente trabalhados por Sade em seu "tratado pedagógico", do qual se servem os preceptores da jovem Eugénie para desmontar todo o aparato moral que nela subsiste, de modo a desbloqueá-la, em seu corpo e em sua imaginação, com vistas a torná-la apta para usufruir todo o prazer a que tem direito. 
Dolmancé, um dos preceptores mais libertinos de Eugénie, enuncia em um dos diálogos com esta jovem, o que pensa acerca da natureza divina e o que a diferencia da natureza humana.

Em primeiro lugar, questiona a existência de Deus. Utiliza-se das contradições observadas internamente ao próprio discurso que acredita em uma natureza divina, justa e boa, que, segundo o autor, jamais se poderia "harmonizar com as injustiças inerentes às leis da natureza"' (1968, p. 38),

Em seguida, argumenta que mesmo admitindo-se a existência de Deus, seria absurdo conceber uma mesma natureza para o agente criador (Deus) e o ser criado (Homem). Finalmente expõe os argumentos materialistas que destroem os fundamentos da religião e da moral. "Qual é, portanto, o agente criador? Eis a única dificuldade a se resolver; a única resposta à qual se responder. Se a matéria age e se movimenta como resultado de combinações que nos são desconhecidas, se o movimento é inerente à matéria, se ela por si mesma pode, enfim, através de sua energia, criar, produzir, conservar, manter, equilibrar nos enormes espaços todos os globos cuja visão nos surpreende e cuja marcha uniforme, invariável, enche-nos de respeito e admiração, qual será a necessidade de buscar um agente estranho a tudo isso, visto que esta faculdade ativa se encontra essencialmente na própria natureza, e que não é outra coisa senão a maténia em ação?' '(1968, p. 38, o grifo é nosso).

$\mathrm{Na}$ verdade, o pensamento materialista de Sade aproxima-se daqueles que defendem uma filosofia baseada na razão e na experiência, que tem como objeto a natureza, considerando a moral como pertencente à esfera do arbitrário. A idéia de pacto social vincula-se, desse modo, ao campo moral; segundo o Marquês de Sade, a necessidade de convenções, proclamada por Rousseau, deve-se ao fato deste pressupor que o Homem seja um animal por excelência indócil.

A filosofia sadiana prega que devemos nos entregar à natureza de modo a buscar o prazer, que, ao mesmo tempo, se confunde com a verdade. Já a moral, espaço da convenção, do artifício, impõe a necessidade de frear os impulsos naturais, se quisermos viver em sociedade.

Essa distinção entre os campos filosóficos e moral cria bases para a diferenciação entre espaço privado e espaço público, fundamental no pensamento de Sade. Este autor aponta para o declínio do espaço público, salientando que o agir verdadeiro só pode se dar no espaço privado. Este não se constitui como espaço de reclusão, mas de subtração do império da lei, da convenção, da renúncia consciente ao social, necessidades estas que se impõem para que a natureza possa florescer. É por isso que a filosofia para Sade só pode ser concretizada na alcova, na qual emerge o fluxo do prazer "maquinal".

Barthes salienta que o Eros sadiano é basicamente estéril e o seu modelo de realização é o trabalho, pois que a orgia passa pelo planejamento, a organização e a distribuição; é comandada e vigiada tal como em "uma sessão de ateliê", em que a "máquina" torna-se "o emblema sublimado do trabalho, na medida em que realiza e, simultaneamente, o exonera" (p. 125). Descreve em seguida o mecanismo de 
funcionamento dessa "máquina" de produzir prazer: "crianças, ganimedes, preparadores, todos eles formam um imenso e subtil mecanismo, uma delicada relojoaria, cuja função é ligar a friç̧ão, produzir um tempo contínuo, levar o prazer ao sujeito sobre um tapete rolante (o indivíduo é engrandecido como princípio e finalidade de toda a maquinaria e, no entanto, negado, reduzido a um pedaço do seu corpo)" (p. 125).

Seguindo os princípios de sua filosofia, Sade desmonta uma a uma as teses da Bíblia, salientando que a História Cristã se impôs, de modo ilusório, a um povo que nela acreditava como uma alternativa revolucionária ao despotismo dos imperadores. Mas, em nome desse ideário de libertação, o Cristianismo acabou impondo o despotismo das "virtudes", exaltando a caridade e a filantropia.

No discurso "Franceses, ainda um esforço, se quereis ser republicanos", Sade defende que o Cristianismo é incompatível com o ideário republicano, já que aquele desde sempre sustentou seu próprio poderio e o dos reis por meio da tirania e das superstições.

Propõe a total derrocada do Cristianismo de modo a possibilitar a edificação da República: "Vós, que tendes na mão a força, desferi o último golpe na árvore da superstição, não basta cortar os ramos: desenraizar completamente uma planta cujos efeitos são de tal forma contagiantes, convencei-vos de que o vosso sistema de liberdade e igualdade contraria tão absolutamente os ministros dos altares de Cristo, que não há um só que os adote de boa-fé ou que não procure abalá-los, se conseguir retomar algum poder sobre as consciências"' (Sade, p. 121).

Defende uma educação nacional que vise a formação de "homens livres", livres do preconceito e da superstição. Exalta, em oposição às virtudes cristãs, o egoísmo e o interesse próprio, ao mesmo tempo que considera mais importante a fruição do prazer do que sua compreensão. "Que um filósofo despretensioso instrua estes alunos sobre as excelências incompreensíveis da natureza; que lhes prove o conhecimento de um Deus, freqüentemente perigoso para os homens, jamais serviu à sua felicidade e, portanto, que não serão mais felizes admitindo como causa do que não compreendem aquilo que compreendem ainda menos: que é menos importante conhecer os misténios da natureza do que fen-la e respeitar suas leis: que estas leis são tão sensatas quanto simples; estão escritas no coração dos homens, e, para adivinhá-las, basta interrogar o coração" (1968, p. 128, o grifo é nosso).

Propõe uma ruptura entre razão e prazer, ou melhor, uma razão sem tutela alguma. Para Sade, haveria uma felicidade original, orgânica, natural, que brotaria do bom funcionamento da máquina corporal. Nesse sentido, a razão, o espírito, o saber e a reflexão podem se constituir em verdadeiras barreiras à felicidade.

Execra a religião, principalmente pelo fato de instituir o remorso, preenchendo de modo ilusório a lacuna entre o privado e o público. "Em menos de seis meses, tudo estará acabado; o vosso deus infame será aniquilado, e isso sem que o indivíduo deixe de ser um justo, zeloso da estima alheia, sem que deixe de temer o gládio das leis e 
de ser um homem honesto, pois que terá sentido que o verdadeiro amigo da pátria não deve, como o escravo dos reis, ser iludido por fantasias; que, em uma palavra, não é a esperança frivola de um mundo melhor, nem o medo de males ainda maiores do que os que nos legou a natureza, ou o único freio, o remorso, que devem conduzir um republicano, que só terá por guia, a virtude" (1968, p. 131, o grifo é nosso).

Vejamos o que pensa Rousseau a respeito da "religião civil". Coloca-se o autor também como crítico do Cristianismo, no entanto, sem deixar de entrever um papel importante da religião na constituição do pacto social, se pensada sob a perspectiva da liberdade de culto.

Distingue três espécies de religião: a do homem, a do cidadão e a dos padres. Para cada uma delas, levanta aspectos positivos e negativos no que se refere ao seu critério último, a capacidade de promover a "unidade nacional". A primeira, a religião do homem, refere-se ao "culto interior ao Deus supremo", e "o que pode dominar de direito divino natural". A segunda, cujos rituais e dogmas restringem-se a um único país, refere-se ao "direito divino civil ou positivo". A terceira impõe aos homens duas legislações, dois chefes, tal como se deu no Cristianismo romano, dele resultando uma espécie de "direito misto".

A terceira é abominada pelo autor logo de início, por implicar a ruptura da unidade social. A segunda é valorizada pelo fato de reunir "o culto divino e o amor das leis", mas é criticada por estar alicerçada sobre o "erro e a mentira" e conduzir os homens ao "estado natural de guerra contra todos os outros" (Rousseau, p. 133). Quanto à primeira, a religião dos homens, apesar de ser reconhecida pelo autor como sublime e verdadeira, peca por não ter nenhuma relação com o corpo público.

Sua veia iluminista o faz criticar os preceitos idealistas do Cristianismo. "O Cristianismo é uma religião toda espiritual, preocupada unicamente com as coisas do céu. A pátria do cristão não é deste mundo" (p. 131). O pacto social, necessário por ser o único capaz de frear os impulsos naturais humanos, não é garantido pela caridade cristã. Esta impõe a resignação diante de todo mal e injustiça, além de condenar o recurso à violência, mesmo quando utilizado em defesa dos princípios mantenedores da coesão e equilíbrio sociais.

Rousseau de modo algum advoga, no campo político, uma República Cristã. Mas, diferentemente de Sade, não pretende impor a eliminação de todo e qualquer culto, acreditando que até seja conveniente ao Estado "que cada cidadão possua uma religião que o faça amar os seus deveres' ' (p. 133). Defende uma religião, cujos dogmas sejam poucos e simples, ou seja, apenas o necessário para a manutenção do pacto social. De outro lado, critica veementemente todo e qualquer tipo de intolerância religiosa, que se torna, a seu ver, intolerância civil, e, por isso mesmo, pode ser extremamente perigosa para a paz e a unidade nacional.

Falemos, então, sobre as idéias de Sade acerca dos costumes, apresentados na segunda parte do discurso "Franceses ainda um esforço, se quereis ser republicanos". 


\section{Os costumes}

Segundo Sade, rompendo-se com o Cristianismo e com o culto da divindade, "com eles desaparecem todos os delitos religiosos, todos os que se conhecem pelos nomes vagos e indefinidos de impiedade, sacrilégio, blasfêmia, ateísmo etc., todos os que, em uma palavra, Atenas puniu tão injustamente em Alcebíades, e a França o infortunado La Barre"' (p. 132-133, grifos no original).

Sade critica, inicialmente, a máxima do Cristianismo, "amarás o próximo como a ti mesmo", já que para ele, em primeiro lugar, o amor é ilusório, enganoso e, em segundo, seria o mesmo que exigir de um exército que se vestisse com uma "farda talhada com a mesma medida".

Critica também preceitos gerais como humanidade, fratemidade e canidade, que, quando impostos a todos, como leis universais, impedem ou reprimem as diferenças individuais.

Em seguida passa a defender a idéia de que a sociedade deve ter o menor número possível de leis que sejam facilmente adaptáveis ao caráter de cada um. "Mas as leis poderão ser tão benignas, em número tão limitado, que todos os homens, seja qual for o seu caráter, se possam submeter facilmente a elas"' (1968, p. 134).

No entanto, quando discursa sobre a questão do assassinato e da pena de morte, fica claro que Sade propõe preferencialmente a dissolução do pacto, que ainda se mantém na idéia de um pequeno número de leis.

Condena a pena de morte por duas razões. A primeira refere-se à diferença entre a lei e a natureza humana que, por não ter os mesmos motivos, não pode outorgar-se os mesmos direitos. Ou seja, "o homem recebe da natureza impulsos que podem fazê-lo perdoar tal ação, e a lei, pelo contrário, sempre em oposição à natureza e nada recebendo desta, não pode ser autorizada a se permitir os mesmos desatinos" (Sade p. 135). A segunda razão refere-se ao despropósito contido na pena de morte, já que pretende eliminar, ou reprimir, uma ação condenável (assassinato) cometendo o mesmo crime.

A primeira argumentação, principalmente, abre caminho para uma proposta amoral, que é justificada por Sade pela necessidade de se dar vazão aos impulsos que a natureza concede aos homens: a calúnia, o roubo, os delitos em geral e o assassinato.

Em alguns momentos de sua argumentação sobre cada uma dessas "perversidades", ironiza a tese da igualdade que subjaz ao pacto social, e se utiliza dos critérios de "justiça" implícitos no pacto para desmascará-lo, ao mesmo tempo que autoriza o delito.

Alguns trechos de A filosofia na alcova são bastante esclarecedores: "Ora, pergunto-vos, agora, se é justo a lei que ordena, ao que nada tem, que respeite o que possui tudo. Quais são os elementos do pacto social? Não consiste ele em ceder um pouco da sua liberdade e das suas propriedades para assegurar e manter o que se conserva de um e de outro?" (p. 138). Na verdade, nos termos em que coloca o pacto fica claro que este só interessa à classe dominante, e a tese da igualdade não passa 
de uma farsa. Em seguida, acrescenta: "com que direito os que não possuem nada subjugar-se-ão a um pacto que somente protege os que têm tudo?"' (p. 138).

Posteriormente procede à análise das ações que a libertinagem pode inspirar, ou seja, a prostituição, o adultério, o incesto, a violação e a sodomia.

Parte de uma questão essencialmente política para justificar que tais ações não devam ser consideradas como crimes pela República. Segundo ele, um Estado tornado "imoral" pelas suas obrigações, não poderá exigir que a conduta de seus cidadãos seja moral. E acrescenta: "Digo mais: é bom que não o sejam" (p. 139, grifos no original).

Desmonta a tese de que o pudor seja uma virtude, mas ao contrário "um dos primeiros efeitos da corrupção, um dos primeiros assomos da futilidade das mulheres" (p. 140). É da nudez, esta sim considerada uma virtude, do impudor, que nascem os "pretensos crimes", cuja primeira conseqüência é a prostituição.

Ficam mais evidenciadas, desse modo, as teses de Sade sobre a verdade: a única moralidade aceitável é a do próprio indivíduo, em que prevalecem o interesse próprio, o prazer e o egoísmo. Guiando-se por essa moralidade, cada indivíduo passa a ser apenas instrumento de prazer para o outro. A paixão, ou o prazer físico, se impõe como uma necessidade mesmo tirana. E se os homens são naturalmente cruéis, então deve-se ir até o fim para a obtenção do prazer. Segundo os ditames dessa paixão, "o homem gosta de ordenar, de ser obedecido, de cercar-se de escravos obrigados a satisfazê-lo; ora, sempre que não fornecerdes ao homem o despotismo que a natureza arraigou no fundo do seu coração, ele se disporá a exercê-lo sobre os objetos que o rodeiam e perturbará o governo"' (p. 141, o grifo é nosso). E é justamente para evitar este perigo, que um governo republicano deve dar livre acesso a tais "desejos tirânicos".

Ao mesmo tempo que se mostra favorável à libertação feminina do jugo do casamento, execrando todo direito de posse sobre a mulher ou sobre qualquer outro ser humano, recorre às dádivas que a natureza concedeu ao homem, ou seja, sendo este mais forte que a mulher, justifica o direito que os homens têm de "estabelecer leis que as obriguem a ceder aos ardores daqueles que a desejam, sendo a violência um dos efeitos de tal direito..." (p. 144). No entanto, salienta que está apenas se referindo ao prazer, e não à propriedade.

Em seguida procecie a uma verdadeira "desmontagem" dos princípios da felicidade burguesa e romântica. Em oposição ao amor, que considera ilusório porque conduz à cegueira com relação ao objeto, exalta o "direito" das mulheres à prostituição. Na base do amor está o desejo e nada justifica o estabelecimento de laços eternos. "O amor, que se poderia chamar a loucura da alma, não tem outros títulos a legitimar sua constância; satisfazendo apenas a dois indivíduos, o ser amado e o ser amante, não pode servir à felicidade alheia, e foi para a felicidade geral, e não para uma felicidade egoísta e privilegiada que as mulheres foram criadas'"(p. 144).

O direito do gozo sobrepuja-se a todos os outros, o que justifica diversos delitos: o incesto, a sodomia, a posse pela força de uma mulher, mesmo que de tenra idade, $\mathrm{o}$ adultério etc. 
A compensação que oferece à mulher, por arrogar-se o direito de dela usufruir para obter o prazer a qualquer preço, é "permitir que elas se satisfaçam amplamente; as nossas leis a respeito devem favorecer o seu temperamento ardoroso, e é absurdo colocar a sua honra e sua virtude na força antinatural que elas empregam em resistir às inclinações que receberam com mais intensidade que nós" (p. 145). Neste momento, está se referindo às inclinações femininas ao prazer que considera mais intensas que as dos homens.

Finalmente, levanta diversos argumentos do ponto de vista político e das relações sociais, favoráveis ao assassinato. Compara o ser humano aos outros bens da natureza, ao mesmo tempo que justifica o assassinato, considerando-o não como um ato de destruição, pois que nada se aniquila na natureza, mas como um ato de transformação. Na verdade, parece-nos mais um argumento formal para tudo justificar em função do prazer, se bem que apoiado em suas teses materialistas, segundo as quais identifica-se no homem a necessidade de fruição de um prazer maquinal, sem nenhuma orientação teleológica que extrapole o próprio prazer.

Em A filosofia na alcova, Sade chega a defender princípios que podemos identificar como fascistas, quando convida a República ao aprimoramento da raça: "todo indivíduo que nasce sem os requisitos necessários para se tornar, um dia, útil à República, não tem qualquer direito de conservar a vida, o que se pode fazer de melhor é eliminá-la no momento em que ele a recebe" (1968, p. 160, nota 18).

Pode-se concluir que Sade, ao contrário de Rousseau, pretende romper com todo e qualquer laço social. Na verdade, libertando o homem das falsas virtudes, dos preconceitos, vai convidá-lo ao crime. O outro deve apenas se constituir como condição de acesso ao prazer.

\section{Sade e Rousseau no contexto filosófico do século XVIII}

Lebrun, no artigo "Les Perils de la Nature", em que analisa as idéias de Sade e de Rousseau em meio a outros pensadores do século XVIII, remete o Marquês de Sade à "inocência de um século venturoso onde a psicologia era ainda balbuciante" (1967, p. 1). As filosofias da época, segundo o autor, na tentativa de esclarecer os "enigmas" da afetividade, recorreram às categorias da "paixão" e da "natureza", cujos sentidos foram se transformando lentamente. O "otimismo" reinante no século XVIII é colocado em dúvida em particular pelos partidários do prazer, os libertinos, dando lugar a um "pessimismo" que invade o final do século - "lassidão do ritual erótico, desprezo das teodicéias, ceticismo à natureza humana..." (p. 2). Lebrun propõe que a redescoberta das obras "malditas" de Sade seja referenciada ao pessimismo de seu tempo.

De modo a alinhavar as idéias esparsamente colocadas no presente ensaio, em particular no que se refere ao contraponto entre Sade e Rousseau, acreditamos que 
seria interessante recorrer à análise de Lebrun em relação às doutrinas, a que se opõe a corrente pessimista, na qual se insere o "sadismo".

Vejamos, então, algumas características do pensamento "otimista". Envolve um utilitarismo, fundado teologicamente, segundo o qual toda obra divina converge para a felicidade terrestre. Essa tese apóia-se, basicamente, em dois postulados:

1. o mundo é uma "totalidade harmoniosa", um dispositivo montado por Deus para se constituir em universo psíquico, tal como aparece em Malebranche ou Leibniz. Rousseau, no entanto, levanta a contrapartida dessa tese quando opõe a ordem natural à desordem, ao caos do gênero humano;

2. a perfeição que a corrente otimista supõe como dada advém do próprio poderio da natureza, e não da vontade do Ser Humano. Malebranche e Rousseau crêem, no entanto, em uma corrupção da natureza promovida pela sociedade, tanto que Rousseau exclui de seu "estado de natureza" o instinto de sociabilidade.

A natureza, tal como é descrita pela corrente otimista, constitui-se enquanto origem da cultura: "ela a antecipa ao mesmo tempo que a engendra" (p. 4). De acordo com esta concepção, a natureza seria o ponto zero de toda normatividade.

Rousseau levanta sérias críticas à postura otimista, ao argumentar que tal "naturalismo" faz total abstração da sociedade, já que a supõe perfeita. A sociedade passa a ser concebida como sendo resultado de contingências históricas e a "natureza" não pode ser definida como uma espécie de vocação social, mas como a condição animal do Ser Humano anterior ao estabelecimento da comunicação. Emerge, a partir dessa concepção, uma lacuna entre a "espontaneidade" e a "civilização".

Rousseau opõe-se à idéia de "sociedade natural", defendida por Diderot, argumentando que não pode existir um pacto social "inato", a não ser na cabeça de tais filósofos que nada mais fazem do que mascarar os antagonismos sociais.

Holbach, segundo Lebrun (1967), oferece em seu Traité de morale todos os sofismas, extremamente conformistas, que Rousseau condena. A regulação das paixões humanas, segundo Holbach, faz-se em função do bem comum, mas obedece "a uma destinação mais profunda que transfigura a motivação egoísta. Essa moralidade orientada teleologicamente é refutada em a Crítica da razão prática, de Kant, obra em que este pensador levanta questionamentos à idéia de que haveria uma virtuosidade inata. Segundo Rousseau, esse otimismo presente em Holbach nada mais faz do que evitar a questão da essência política da moralidade. Não se explicita que as tendências "naturais", apontadas por Holbach como essenciais à sociedade, refletem, na verdade, a concepção que a burguesia tem a esse respeito: a "Natureza aperfeiçoada" (p. 6).

As correntes "pessimistas" refutam exatamente esse tipo de verdade veiculada pelas tendências "otimistas". Rousseau e Kant, como já foi assinalado anteriormente, são seus maiores representantes, ao lado de alguns "hedonistas lúcidos", tal como salienta Lebrun, referindo-se a Maupertuis, Prévost e La Mettrie. O prazer é apresentado por esses autores como inteiramente indiferente às normas sociais; a moralidade 
não aparece mais como enraizada em nosso "coração". Deixa de haver uma relação essencial entre a virtude e o prazer.

Lebrun, no artigo citado, salienta que se trata de uma crítica negativa das ilusões éticas, cujo temário pode ser agrupado numa tripla contestação.

1. Contestação da moralidade naturalista - As tendências naturalistas são estranhas a toda ordem moral, pois se apresentam intrinsecamente ligadas muito mais à "submissão", do que à "harmonia". Rousseau, se bem que faça certas concessões ao Pathos sentimentalista, denuncia o real significado da palavra "virtude", ou seja, que nada mais é do que o triunfo da moralidade sobre os corpos.

Kant salienta que o conceito de felicidade não se constitui como algo essencial à ética. Tal conceito, bastante genérico, refere-se a uma "natural" inclinação ao bem, que, segundo Kant, significa o cumprimento do dever de acordo com a Lei Moral, mas que aparece sob a rubrica do Bem. La Mettrie, em Anti-Sêneca, defende a idéia de que a conquista da felicidade é indiferente a essa distinção entre o Bem e o Mal, e que talvez seja mais honroso obter satisfação em fazer o Mal do que em fazer o Bem. Na verdade, tal afirmação se constitui em uma provocação à moralidade burguesa, representada pela corrente otimista, ao mesmo tempo que aponta para o reconhecimento das tendências agressivas no Ser Humano. Kant reconhece que não há felicidade sem prazer e que se constitui em um paradoxo afirmar que a felicidade faz-se apenas pela "consciência do mérito", colocando-a como algo independente da natureza.

La Mettrie, embora proponha o rompimento com o espaço social como condição da felicidade, numa linha ainda epicurista, defende a necessidade de se estabelecer vínculos entre os homens. Não convida ninguém ao crime, mas propõe a paz de espírito diante do ato criminoso realizado, pois ainda mantém, ao contrário de Sade, a necessidade de uma razão tutelada pelo interesse coletivo. Nesse sentido, La Mettrie salienta as diferenças entre prazer e virtude, sem, no entanto, excluir totalmente esta última, tal como propõe o Marquês de Sade.

Outra questão criticada por essa corrente de pensadores pessimistas em relação ao otimismo conservador é a necessidade de estabelecer uma "hierarquia ética de prazeres" em que se privilegia os prazeres dos sentidos. Para aqueles, trata-se de um único prazer e os libertinos de Sade realizam-no soberanamente, sem desvincular a reflexão filosófica da ética dos prazeres.

2. Contestação da noção de ordem como antropomorfismo - Não há ordem na Natureza, nem mesmo qualquer espécie de legalidade. A própria expressão "lei natural" é controvertida. La Mettrie, por exemplo, fala de "uma pretensa lei natural", enquanto Sade sempre considerou-a absurda.

Enquanto Sade proclama que nada aparta o homem da Natureza, Rousseau considera que o homem é um "agente livre", ou seja, o único capaz de se libertar das determinações de qualquer espécie de animalidade natural.

3. Contestação da utopia das onigens - Lebrun afirma, no artigo citado, que diversos autores do século XVIII, como Diderot, Buffon, Condillac, Rousseau, fazem remontar a questão das origens às coordenadas antropológicas. 
Encontra-se, em particular no pensamento de Rousseau, uma utopia bastante contestável a esse respeito. Ele, que não vê na vida social senão injustiças e violência, faz uma exceção no que se refere ao comércio sexual, na medida em que considera essencial, para que este se efetue, o acesso à cultura. O amor é visto, pois, como uma "instituição artificial por excelência". O onanismo, no entanto, é considerado como algo antinatural.

Lebrun finaliza seu artigo demonstrando como todos esses autores, mesmo que numa linha antropológica, abrem caminho para uma temática que, no século XIX, passa a ser designada como a "sexualidade".

Parece-nos que é a esse pessimismo identificado por Lebrun no pensamento de Sade, que Adorno e Horkheimer recorrem para situá-lo nos quadros de uma Filosofia Negativa, já que se trata de um pessimismo quanto aos rumos do existente, tornando-se, por isso mesmo, crítico.

\section{Sade - uma filosofia negativa?}

Sade, diferentemente de Rousseau e mesmo de La Mettrie, aponta para a necessária ruptura razão e prazer. Neste sentido, procede a afirmação dos autores da Dialética do esclarecimento de que a realização de idéias como as de Nietzsche e Sade, em um projeto histórico-universal, tal como se configurou posteriormente na ideologia fascista, acabou produzindo efeitos contraditórios: de um lado, findou por negar que essas filosofias proclamassem a vida, de outro, demonstrou seu conteúdo de verdade ao apontar os rumos do existente.

Nessa mesma obra, Adorno e Horkheimer acrescentam que o arrependimento e a compaixão foram execrados por Nietzsche e Sade, porque ambos sabiam que "a doutrina da pecaminosidade, da compaixão era uma velha herança burguesa" (1985, p. 98). Afirmam também que a compaixão não estava presente na filosofia kantiana: "Para Kant, ela é uma certa sentimentalidade e não teria em si a dignidade da virtude" (p. 98).

Assim é que essas filosofias pretenderam, com esse horror à compaixão, impedir que o homem fosse visto, em sua infelicidade, como objeto de lamentações. Esses autores opunham-se exatamente às " deformações narcísicas da compaixão", presentes nas práticas de filantropos e assistentes sociais, que representam "a confirmação interiorizada da diferença ricos e pobres" (p. 99). No entanto, esse "prazer pela dureza", proclamado por essas filosofias, acabou colocando o ser humano à disposição daqueles que menos se abriam à sua confissão: "Os fascistas que dominaram o mundo traduziram o horror pela compaixão no horror pela indulgência política e no recurso à lei marcial, no que se uniram a Schopenhauer, o metafísico da compaixão" (p. 99).

Contraditoriamente, os autores salientam que essas doutrinas sem compaixão tornaram-se mais misericordiosas do que "as doutrinas dos lacaios morais da burgue- 
sia" (p. 112). Negando a compaixão, acabaram por afirmar a "confiança inabalável no homem, traída cada vez que se faz uma afirmação consoladora" (p. 112).

Adorno e Horkheimer apontam para o irracionalismo da razão instrumental, que tem na Filosofia do Esclarecimento sua utopia realizada, ou seja, a criação de um paraíso para a Humanidade, cuja pretensão é converter toda a natureza em forças domesticadas a serviço do Homem e de seus prazeres. O domínio da natureza, no entanto, transforma-se em seu contrário, quando os produtos do trabalho humano passam a dominar o próprio homem. A realização do fetiche da mercadoria se completa quando o trabalho visa valorizar o capital e não o provimento de necessidades. Evidencia-se, desse modo, a irracionalidade desse processo e da própria Filosofia do Esclarecimento que o mantém, referindo-se em particular a autores como Bacon, Comte e os neopositivistas.

Somente uma razão emancipatória é que poderia se contrapor à razão instrumental, rompendo com o círculo encantatório (o fetiche) do mundo das mercadorias.

Filosofias Negativas como as formuladas por Kant, Hegel, Nietzsche, Freud e mesmo a de Sade, são apresentadas pelos autores como as que podem fornecer os fundamentos críticos necessários para se contrapor à razão instrumental.

AMARAL, M. G. T. do. The rupture of the social contract in Sade's thought. Trans/Form/Ação, São Paulo, v. 15, p. 65 - 83, 1992.

- ABSTRACT: The works of Sade portray the corrupt and libertine practices at the time of Louis XV'S despotic regime, invariably referning to the boudoir as a privileged place for the transformation of mind and body as well as for philosophical production. The actuality of Sade's thoug ht lies in the fact that he reveals - as do modem trends - the narcissic constitution of subjectivity that, in its social-political aspect, leads to political conformism. This article aims at presenting Sade's thought as a radical critique of social relationships, which lead to the rupture of Rousseau's social contract. His relentless doctrine becomes negative philosophy in that it supplies the foundations for the critique of instrumental reason. A pessimist regarding the course of social totality, Sade's theory points to human 'animality' as a possible means of transcending the artificiality of social relationships.

- KEYWORDS: Anti-humanist philosophy; truth; sexuality; transcendency.

\section{Referências bibliográficas}

BARTHES, R. Sade, Fourier, Loiola. Trad. Maria de Santa Cruz. São Paulo: Martins Fontes, 1979.

HORKHEIMER, M., ADORNO, T.W. Dialética do esclarecimento: fragmentos filosóficos. Trad. Guido Antonio de Almeida. Rio de Janeiro: Zahar, 1985.

JAY, M. Positive and negative totalities: implicit tensions in critical theory's vision of interdisciplinary research. In: Permanent exiles: essays on the intelectual migration from Germany to America. New York: Columbia University, 1986. 
LEBRUN, M. Les perils de la nature. São Paulo: USP, 1967. 14p. (Mimeografado)

ROUSSEAU, J.J. O contrato social e outros escritos. Trad. de Rolando Roque da Silva. 5. ed. São Paulo: Cultrix, s.d.

SADE, D.A.F. de. A filosofia na alcova. Trad. Martha A. Haecker. Rio de Janeiro: J.C.M., 1968.

SADE, D.A.F. de. A verdade e outros textos. Trad. Luiza Neto Jorge e Manuel João Gomes. Lisboa: Antígona, 1989. 